\title{
SOILS AND SEDIMENTS OF PROŠĆE LAKE CATCHMENT AS A POSSIBLE TERRIGENOUS INPUT IN THE LAKES SYSTEM
}

\author{
TLA IN SEDIMENTI ZALEDJA PROŠČANSKEGA JEZERA \\ KOT MOŽEN TERIGEN DOPRINOS V JEZERSKI SISTEM
}

\author{
Anita PTIČEK SIROČIĆ ${ }^{1 *}$, Stanislav KURAJICA², Dragana DOGANČIĆ ${ }^{1} \&$ Nikolina FIŠTER $^{1}$
}

\begin{abstract}
UDC 631.41:502.51(497.5Proščansko jezero) Anita Ptiček Siročić, Stanislav Kurajica, Dragana Dogančić \& Nikolina Fišter: Soils and sediments of Prošće Lake catchment as a possible terrigenous input in the lakes system

The Plitvice Lakes National Park is in the northwestern part of the Dinaric Karst in central Croatia. An important role of the soil in the karst is to purify the waters before they reach the phreatic zone. The soil is also a zone of accumulation, transformation, retardation and dilution of a potential pollutant. Knowing soil mineralogical composition is an important factor in understanding fate and transport of contaminants throughout lakes system. Samples of soil, peat and stream sediment were collected in the Prošće lake catchment and partly in the assumed zone of influence, X-ray diffraction (XRD) and Fourier Transform Infrared spectroscopy (FTIR) analysis of samples was performed to determine dominant mineral species in samples. XRD analysis showed predominance of lowquartz, which was found in all samples, most often as dominant phase. Dolomite was found in half of the samples, almost always as a significant phase while calcite was dominant phase in one of the samples. In most of the samples, members of the feldspars and chlorites groups, as well as muscovite, were present as minor phases. The absorption bands in the range of $2800-3000 \mathrm{~cm}^{-1}$ due to the organic matter are visible in spectra of all samples. These minerals can enter lakes system by surface waters, primarily streams and overland flow during snow thawing and rain, and also in cases of shore erosion. Terrigenic input in lakes is small but cannot be neglected due to the longlasting preservation efforts of the Prošće Lake recharge area, and the Plitvice Lakes National Park in general, terrigenous intake still does not pose a threat to water quality and tufa production.
\end{abstract}

Izvleček UDKs 631.41:502.51(497.5Proščansko jezero) Anita Ptiček Siročić, Stanislav Kurajica, Dragana Dogančić \& Nikolina Fišter: Tla in sedimenti zaledja Proščanskega jezera kot možen terigen doprinos v jezerski sistem

Narodni park Plitviška jezera se nahaja v severozahodnem delu Dinarskega krasa v osrednji Hrvaški. Pomembna vloga tal v krasu je, da čistijo vodo, preden doseže freatično cono. Tla so tudi območje, kjer se potencialna onesnaževala kopičijo, preoblikujejo in redčijo. Tla ta onesnaževala tudi zadržijo. Poznavanje mineraloške sestave tal je pomemben dejavnik pri razumevanju prenosa onesnaževal v jezerskem sistemu. Tla, šoto in sedimente smo vzorčili v neposrednem zaledju in na vplivnem območju Prošćankega jezera. Mineralne vrste smo določili z rentgensko difrakcijo (XRD) in infrardečo spektroskopijo s Fourierjevo transformacijo (FTIR). Analiza XRD je pokazala, da v vzorcih prevladuje kremen, ki je bil v vseh vzorcih ugotovljen kot prevladujoč mineral. Dolomit je bil najden v polovici vzorcev, skoraj vedno kot pomemben mineral, medtem ko je kalcit prevladoval samo v enem od vzorcev. V večini vzorcev so bili v manjšini še glinenci, kloritni minerali in muskovit. Absorpcijski pasovi na območju $2800-3000 \mathrm{~cm}^{-1}$ so bili zaradi organske snovi vidni v vseh spektrih.

Minerale lahko v jezerski sistem prinesejo površinske vode, predvsem med taljenjem snega in ob padavinah ali obalni herozijskih procesi. Terigeni vnos je majhen, vendar ga zaradi dolgotrajnih prizadevanj za ohranitev in obnovo območja Prošćanskega jezera ni mogoče prezreti. Verjetno pa še ne ogroža kakovosti vode in nastajanja lehnjaka.

Rezultati kažejo, da tla in sedimenti v zaledju Proščanskega jezera učinkovito zadržijo in čistijo vodo na poti do jezera. Vseeno lahko ob morebitnem onesnaženju v zaledju onesnaževala dosežejo jezerski sistem, če so adsorbirana na delce tal. Pozna-

${ }^{1}$ Faculty of Geotechnical Engineering, University of Zagreb, Hallerova aleja 7, 42000 Varaždin, e-mail: aanitaps@gfv.unizg.hr; ddogan@gfv.unizg.hr; nfister@hotmail.com

${ }^{2}$ Faculty of Chemical Engineering and Technology, University of Zagreb, Marulićev trg 19, 10000 Zagreb, e-mail: stankok@fkit.hr

* Corresponding Author 
Considering the analyzed samples and characteristics of detected soil constituents, soils and sediments in the Prošće Lake catchment have the ability to retain and purify water on its way to the lakes. On the other hand, in case of the possible contamination in the recharge area of the lakes system, the pollutants can enter the system adsorbed on the soil particles. Learning more about the soils surrounding lakes gives valuable insight into their possible influence on lakes water chemistry and adds one piece of the puzzle into understanding this kind of a natural phenomenon.

Key words: Plitvice Lakes National Park, FTIR, XRD, soil mineralogy, Croatia. vanje tal v okolici in širšem zaledju jezera omogoča dragocen vpogled na njihov morebitni vpliv na kemijo vode $\mathrm{v}$ jezerih in prispeva $\mathrm{k}$ razumevanju tovrstnega naravnega pojava.

Ključne besede: Narodni park Plitviška jezera, FTIR, XRD, mineralogija tal, Hrvaška.

\section{INTRODUCTION}

Plitvice Lakes is the oldest and largest National Park in the Republic of Croatia. Its unique beauty and vulnerability were recognized by researchers and nature enthusiasts in late 19th and early 20th century which lead to proclamation of National Park on April 8, 1949. In 1979 Plitvice Lakes have entered in the UNESCO World Heritage List and the total area under protection is $296.85 \mathrm{~km}^{2}$.

The Plitvice Lakes National Park is located in the northwestern part of the Dinaric Karst between the mountains Lička Plješevica and Mala Kapela. The Park is situated in two counties, $90.7 \%$ in Lika - Senj County and $9.3 \%$ in Karlovac County (Fig. 1). The Plitvice Lakes catchment is almost entirely within the boundaries of the National Park. Unique geomorphological, hydrological, biogeochemical and biological phenomenon of the Plitvice Lakes attracts around 1 million visitors a year making this area very susceptible to anthropogenic influence.

Three main springs - the Black River, the White River, and the Plitvica spring feed the lakes with waters of exceptional quality. Hydrological system of 16 cascad-

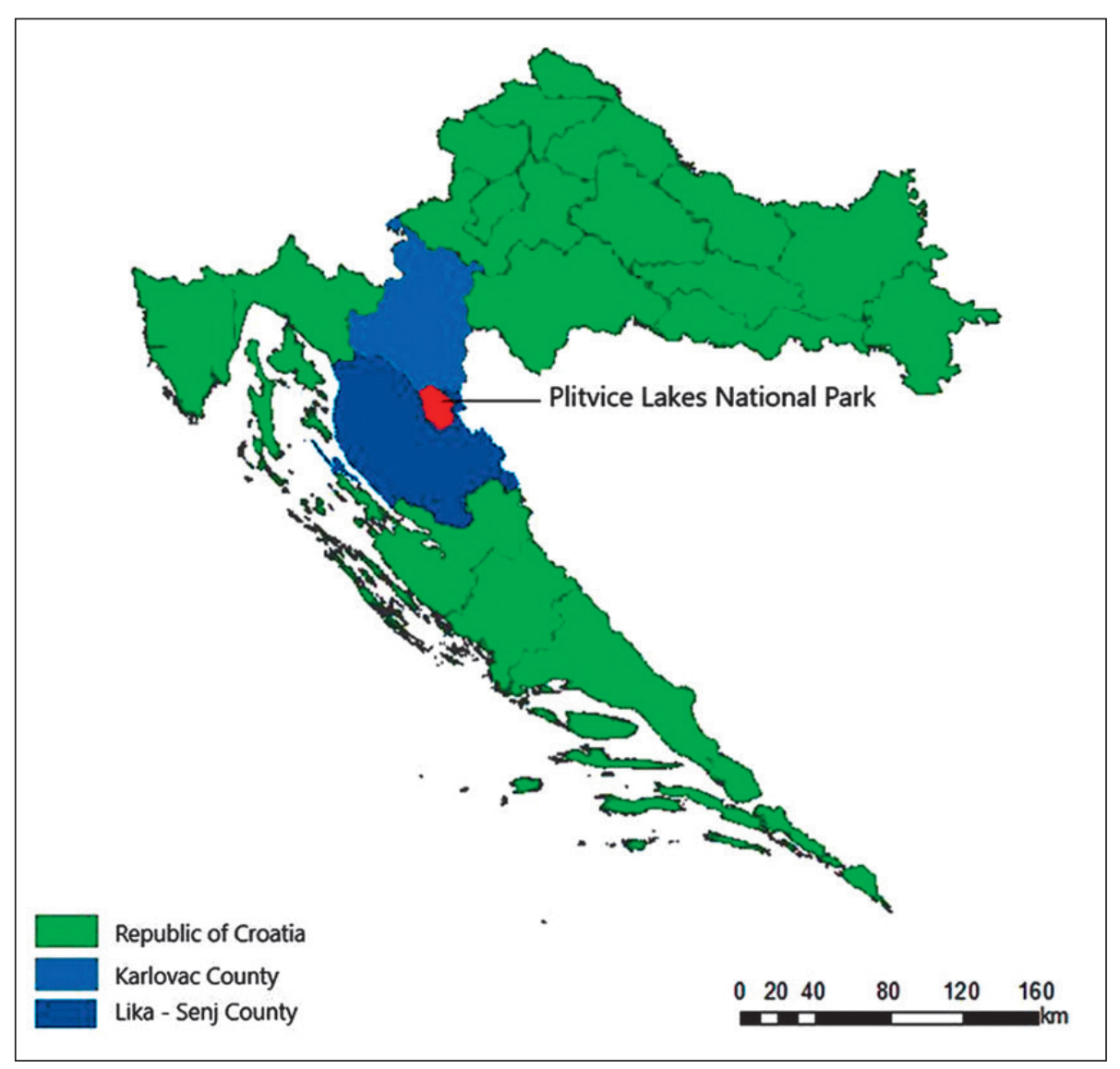

Fig. 1: Position of investigated area (from Matin 2017). 
ing lakes separated by tufa barriers and waterfalls covers about $1 \%$ of the total surface area of the park. The Park is traditionally divided in two parts - 12 Upper lakes, including biggest lakes Prošće $\left(0.68 \mathrm{~km}^{2}\right)$ and Kozjak $(0.82$ $\mathrm{km}^{2}$ ), and 4 Lower lakes. The Upper lakes are developed in the dolomite valley, surrounded by forests and interconnected by numerous waterfalls. Smaller Lower Lakes are located on limestones. Lakes are unique for their autigenic calcite precipitation and a large population of calcifying cyanobacteria. Beside cyanobacteria, other microscopic and macroscopic organisms like diatomeae, protozoa, mosses and algae play very important role in tufa growth process (Meaški 2011). These organisms develop on the rocks and submerged objects. As the tufa barriers grow (1-3 cm/yr.), so does the water level result in changes of lake volume. According to Babinka (2007) total volume of the lakes is $22.95 \times 10^{6} \mathrm{~m}^{3}$.

Water chemistry of mountain lakes is influenced by numerous factors like bedrock mineralogy, amount and composition of soils, slope, exposure and type of vegetation (Kamenik 2001). Changes in global climate trends, watercourse regulations, forestry and agricultural activities, leaking wastewater systems, war, and tourism represented a serious threat for this fragile ecosystem in the last decades (Sremac et al. 2012). Main focus of the researchers during the years has been the development of the tufa barriers and lakes but nowadays interest has shifted to protection of the recharge area of the main springs, protection of the lakes and waterfalls from growing tourism development and broader protection of the karst environment from the impact of the National Park and its activities (Biondić et al. 2008). Focus is also set on chemical and physical properties of soil, since terrigenic input can be a significant source of trace elements in water and lake sediment.

The solid soil phase is a mixture of organic substances and minerals and makes up 30 to $60 \%$ of the total soil content, the rest being air, water and living organisms. Soil mineral phase in some soils make up to $90 \%$ of the soil solid phase (Chesworth 2008). The soil organic matter, depending on the type of soil, makes on average 2-10 $\%$ of the solid phase content of the soil. Soil organic matter is complex mixture composed of products resulting from microbial and chemical transformations of organic debris. Most soil organic matter originates from plant tissue and has a significant effect on the physical, chemi$\mathrm{cal}$, and biological properties of the soil by improving the capacity of a soil to hold water and nutrients which are then released slowly enabling better plant uptake and better conditions for plant growth. Organic matter from allochthonous source area can also enter lakes system via surface runoff during periods of snow thawing and in rain seasons. Source, concentration and composition might be among the factors influencing bacterial community composition and their production, respiration and growth yield in the lakes (Kritzberg et al. 2006).

Thickness of soil cover in the karst areas often varies and its central role is to purify the waters before they reach the phreatic zone. The soil serves as a medium for accumulation, retardation, dilution and transformation of a potential pollutant. Water-borne contaminants that permeate through the soil can be adsorbed onto the soil surface, bound to clay minerals, precipitated or move further through the soil. The effectiveness of soil to protect groundwater from pollution depends on its thickness and composition, but also on other properties such as $\mathrm{pH}$ values, cation exchange capacity and clay mineral content. Composition and properties of the soil is one of the input parameters when assessing the intrinsic vulnerability. Knowledge of the minerals comprising the soil inorganic component makes it possible to understand the weathering of minerals in surface conditions, determination of soil and sediment age and mechanisms of soil formation. Soil mineralogy can also help to explain paleo-environmental conditions during pedogenesis (Chesworth 2008). Also, knowing soil mineralogical composition is an important factor in understanding fate and transport of contaminants throughout lakes system. Related to Halamić \& Miko (2009), during the exploratory works for the project of making a Geochemical map of Croatia sampling of soils of the Plitvice Lakes was carried out. Geochemical analysis of these samples showed no elevated values of heavy metals concentrations.

Majority of methods used nowadays for characterizing soil inorganic constituents were developed by chemists and physicist. Their area of interest were simple systems, unlike soil, but despite that, these techniques found its application in characterization of soil minerals.

Soil organic matter contains different functional groups with dipole moment which strongly influence properties of organic matter. That makes Fourier Transform Infrared spectroscopy (FTIR) a very suitable technique for characterizing soil organic matter functional groups. Numerous $\mathrm{O}, \mathrm{N}$ and $\mathrm{S}$ functional groups make organic matter highly reactive in reactions of cation exchange and sorption of metals. One of the most significant functional group, the carboxyl group $(\mathrm{C}=\mathrm{O})$ can be well-characterized by FTIR spectroscopy (Margenot et al. 2017).

Taking all the stated facts into consideration, it becomes clear that soil mineralogy plays an important role in understanding the behavior of soil. Our aim was to determine main mineral constituents in soil by FTIR and XRD analysis and, based on results, to explain the possible role of detected minerals in environment of the Prošće Lake area. 


\section{GEOLOGICAL AND GEOGRAPHICAL SETTING}

Plitvice Lakes catchment is a part of the Black Sea basin and according to the recent hydrological, hydrogeological and hydrogeochemical explorations the catchment can be divided into 3 subcatchments: Matica River, Lakes and Plitvica Spring subcatchment. Matica River subcatchment covers around $55 \%$ of the total area of the Plitvice Lakes and can be divided into 3 smaller hydrogeological units: the Black River, the White River and
Ljeskovac stream (Meaški et al. 2016). Black and White Rivers bring most of the incoming waters to the lakes and after merging they form the Matica River before entering Prošćansko Lake. Prošćansko Lake is the second biggest and uppermost lake of the Plitvice Lakes system. Makjanić (1971) states that Plitvice Lakes are situated in the area between moderate warm rainy and snowy forest climates. According to Köppen-Geiger climate classifica-

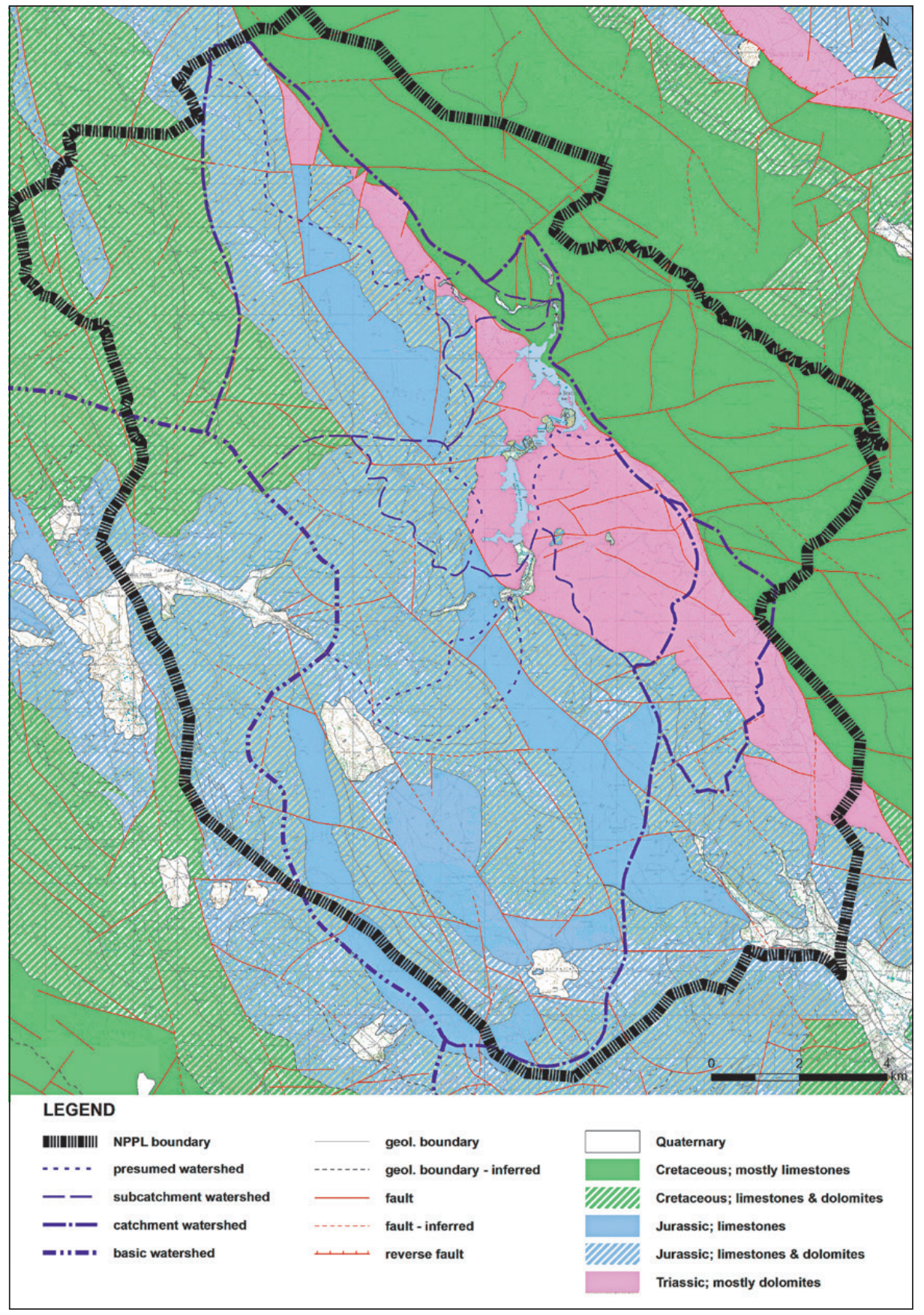

Fig. 2: Geological map of the Plitvice Lakes catchment (from Meaški 2011). 
tion this area has temperate humid climate without a dry season with a warm summer classified as climate type Cfb (Filipčić 1998; Kottek et al. 2006). Thick forests cover about $75.6 \%$ of the area rest being short vegetation and meadows (Bonacci 2013). Forests form a protective zone around the lakes by preventing torrents and soil erosion, regulating runoff and drainage and also purifying rainwater and air. Bearing in mind the key role of forest ecosystems in the hydrological regime of the Plitvice Lakes, the central phenomena of Plitvice Lakes, tufa, is directly linked to the protection and conservation of forest ecosystems.

From geological part of view, the Plitvice Lakes National Park is a karst environment composed of Upper Triassic to Upper Cretaceous carbonate rocks (limestones and dolomites) (Fig. 2). Oldest rocks are Upper Triassic bedded dolomites which predominate around Upper Lakes and around streams Rječica and Sartuk. Poorly permeable Upper Triassic dolomites were essential for the development of the Upper Lakes because they form a barrier to the discharge of water from a large basin on the northeast slopes of Mala Kapela (Biondić et al. 2010). The Black River flows through Lower Jurassic dolomites with intercalations of limestones. The White River and spring Sušanj flow through area built mainly of Upper Jurassic bedded limestones with intercalations of dolomite and massive and crystalline dolomite. Part of their flow goes through the Middle Jurassic bedded limestone with intercalations of dolomite. Upper Cretaceous rock are thick bedded and massive rudist limestone. This type of rocks builds the bottom and the flanks of the north-eastern part of the Kozjak Lake and part of the Korana River (Dautović et al. 2014). Miocene deposits are present in northeastern part of National Park and outside park boundaries. Quaternary deposits appear in the areas of Korenička River, karst poljes Brezovačko and Homoljačko and spring Babin potok.

Tectonics plays very important role in the formation of surface and groundwater systems in the karst environ- ments (Biondić et al. 2010). Carbonate rock are very brittle and crack easily when under pressure. In the Plitvice Lakes National Park limestones and dolomites are fractured into tectonic blocks by numerous faults (Fig. 2).

Soils in the Plitvice Lakes area are classified as automorphic soil. Their main characteristic is wetting through precipitation only with no additional wetting (Halamić \& Miko 2009). The dominant type of soil is calcocambisol or brown limestone soil (soil developed on limestones and dolomites). Along with the calcocambisol, there are also rendzinas, calcomelanosols and luvisols. Surface horizons have a significant amount of humus which effects many soil properties like, moisture and nutrients retention (Vrbek 2005). Soils are loamy in texture and soil cover is $15-80 \mathrm{~cm}$ thick throughout the catchment. In karst poljes soil cover is thicker (up to 2 m). Although $99 \%$ of the Park surface is terrestrial environment, very few studies were conducted of that area. Soils play a very important role in slowing down infiltration of water and contaminants in karst underground (Romanić et al. 2016). According to Kamenik (2001) in case of mountainous lakes, water $\mathrm{pH}$ increases with increasing soil cover.

Lakes are very vulnerable systems due to input of various materials via surface runoff, wastewater discharge and atmospheric deposition (Mikac et al. 2011). In pristine lakes, like the ones in Plitvice Lakes National Park, trace elements input depends primarily on the local geology and weathering rates (Zaharescu et al. 2009). The ability of metals to bind to different particles depends on the specific surface area and affinity for different active sites (Dautović et al. 2014). Mineralogical characterization of complex samples, like soils, is an important way of determining their physical and chemical characteristic and functionality. Mineralogy strongly affects soil-water and soil-water-contaminant interaction and knowledge of the same is very important for solving several problems encountered in geoenvironmental engineering.

\section{METHODS}

\section{SAMPLING}

During the May 2017, 10 samples of soil, peat and stream sediment were collected in the Prošće Lake catchment and partly in the assumed zone of influence (Fig. 3; Tab. 1). Prior to drying, all the impurities like leaves, twigs, branches were removed. Samples were airdried at room temperature to prevent the loss of any volatile elements.
Completely dried samples were milled in agate mortar and sieved. The goal was to get fine enough sample particle size to obtain adequate statistical representation of the components and their various diffraction crystal planes and also to avoid any diffraction related artifacts (Bish \& Reynolds 1989) 


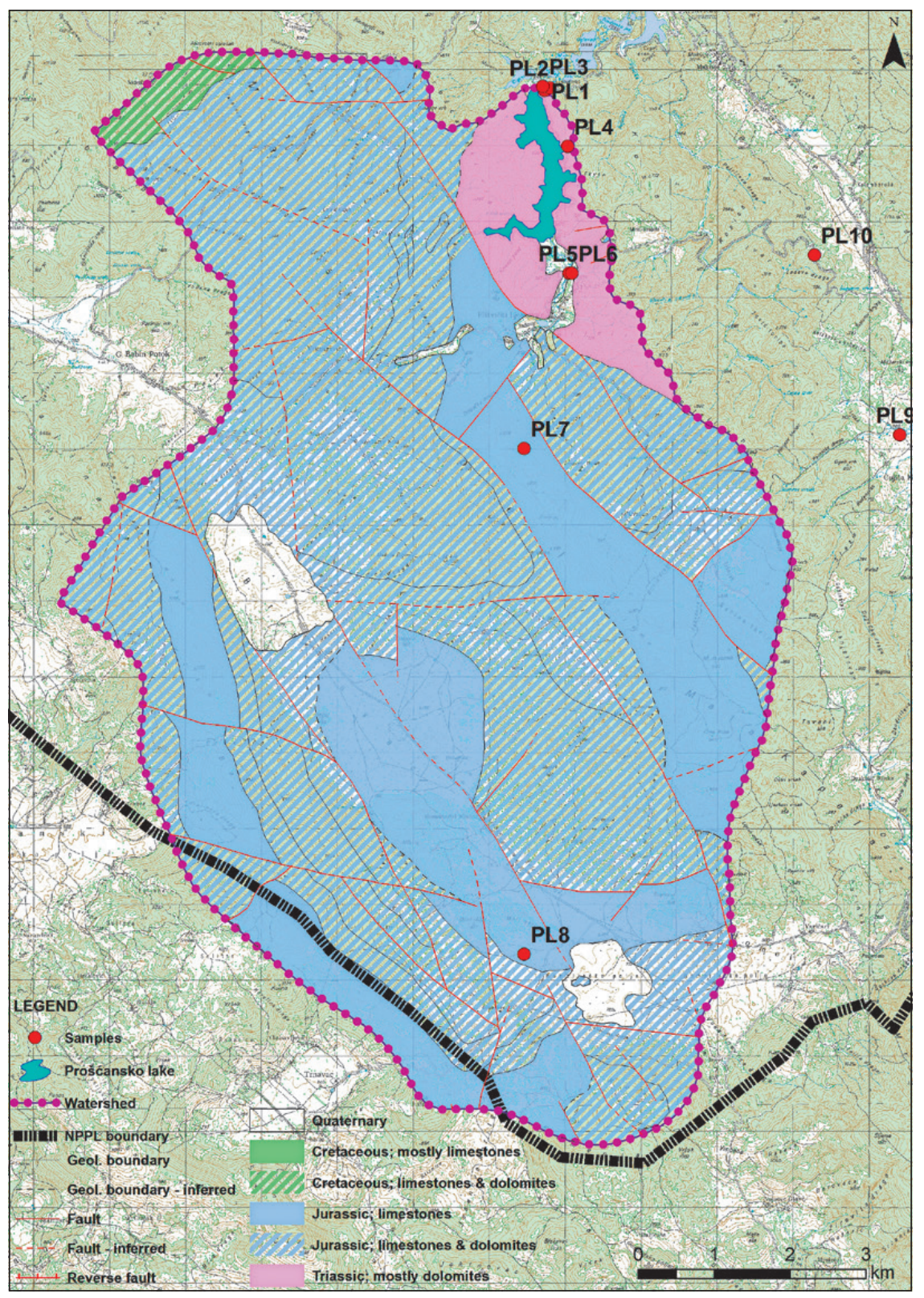

Fig. 3: Geological map of Prošće Lake catchment with soil sampling locations (Meaški et al. 2016).

Tab. 1: Samples description.

\begin{tabular}{|c|c|c|}
\hline Sample & Sample type & Underlying rocks \\
\hline PL-1 & forest soil near lake Prošće & Triassic dolomites \\
\hline PL-2 & meadow soil behind restaurant & Triassic dolomites/tufa \\
\hline PL-3 & stream sediment & Triassic dolomites \\
\hline PL-4 & forest soil near lake Prošće & tufa/Triassic dolomites \\
\hline PL-5 & peat near river Matica & Triassic dolomites \\
\hline PL-6 & soil near river Matica & Jurassic limestones and dolomites \\
\hline PL-7 & soil from sinkhole & Jurassic limestones and dolomites \\
\hline PL-8 & meadow soil outside settlement & Cretaceous limestones and dolomites \\
\hline PL-9 & soil from Uvalica meadow & Triassic dolomites \\
\hline PL-10 & soil at vicinity of local road & \\
\hline
\end{tabular}




\section{FOURIER TRANSFORM INFRARED SPECTROSCOPY (FTIR)}

FTIR analysis has a wide range of applications, from organic synthesis, polymer science, petrochemical engineering to pharmaceutical industry and food analysis. When analyzing the soil, FTIR gives an insight into the composition of the functional groups of present minerals and organic matter. One of the advantages of FTIR is the possibility to identify non-crystalline and amorphous materials (Margenot et al. 2017). The FTIR measurement was carried out using a Perkin Elmer FTIR Spectrum One Infrared Spectrometer equipped with an attenuated total reflection accessory (ATR). All the spectra were acquired in the range from $4000 \mathrm{~cm}^{-1}$ to $600 \mathrm{~cm}^{-1}$ with a spectral resolution of $4 \mathrm{~cm}^{-1}$. Since FTIR is usually used in combination with some other techniques, XRD was chosen as a second characterization technique.

\section{X-RAY DIFFRACTION (XRD)}

$\mathrm{XRD}$ is a rapid analytical technique primarily used for the identification of unknown crystalline materials like minerals and inorganic compounds. X-ray diffraction analysis (XRD) is a technique that provides information on phase composition and crystal structure of the material. Mineral identification is based on d-spacing and relative peak intensities and is much easier if sample contains only one type of the mineral. Soil mineral phase, on the other hand, is a mixture of different minerals who's complex XRD patterns can present a challenge for the identification. One of the main limitations of XRD technique is the detection limit, which is around $1 \%$ of weight (Bruckman \& Wriessnig 2013).

The mineralogical composition of ground bulk soil samples was determined by X-ray diffraction (XRD) analysis using a Shimadzu XRD-6000 equipped with $\mathrm{CuKa}$ radiation operating at $40 \mathrm{kV}$ and of $30 \mathrm{~mA}$. The diffraction patterns were obtained from $5^{\circ}$ to $75^{\circ} 2 \theta$ in a step-scan mode with steps of $0.02^{\circ} 2 \theta$ and counting time of $0.6 \mathrm{~s}$. The mineralogical identification was based on the comparison with a database.

\section{RESULTS AND DISCUSSION}

\section{FTIR}

FTIR analysis of the bulk soil samples determined the presence of quartz in all analyzed samples. Organic matter and clay minerals, most likely kaolinite, are also present in majority of samples. In addition, the minerals in the carbonate group (calcite) and the silicate mineral chlorite have been detected. FTIR spectra of the studied samples are presented in Figs. 4-7.

Detailed examination of the FTIR diagrams of the soil samples revealed different functional groups characteristic for the organic matter. The small band observed at $3380 \mathrm{~cm}^{-1}$ in samples PL-1 (Fig. 4), PL-3, PL-4 (Fig. 5) and PL-8 (Fig. 6) correspond to amide N-H stretch. The bands in the range of $2800-3000 \mathrm{~cm}^{-1}$ and around 1420 $\mathrm{cm}^{-1}$ are due to aliphatic $\mathrm{C}-\mathrm{H}$ symmetric stretching mode vibrations of the organic matter and are visible in spectra of all samples.

A few samples (PL-5 to PL-9) (Fig. 6) have broad band around $1650 \mathrm{~cm}^{-1}$ which is characteristic for aromatic $\mathrm{C}=\mathrm{C}$ bending vibration and/or amide $\mathrm{C}=\mathrm{O}$ functional groups. Samples PL-4 and PL-7 have small bands at 3030 $\mathrm{cm}^{-1}$ which can be attributed to aromatic $\mathrm{C}-\mathrm{H}$ stretching vibrations. Strong peaks visible around 2100 in majority of samples corresponds well with band characteristic for alkynyl $\mathrm{C}=\mathrm{C}$ stretching vibration. Bands characteristic for other important functional groups like polysac- charides $\left(1018 \mathrm{~cm}^{-1}\right)$ most likely overlap with mineral absorbances in the range $1400-800 \mathrm{~cm}^{-1}$ (Margenot et al. 2017). As stated before, soils have very small amount of organic matter in comparison to mineral content. One of the limitations in using FTIR for soil organic matter characterization arises from mineral dominance and interferences, in particular $\mathrm{Si}-\mathrm{O}$ bands.

Soil minerals, through interaction with soil water, affect soil physical properties and behavior like soil plasticity, swelling, permeability to air/water and aggregate stability. Nature of secondary mineral phase that forms in situ during weathering of primary minerals silicate minerals have a significant impact on soil characteristics. Clay minerals are the most abundant secondary minerals that dominate finegrained $(<2 \mathrm{~mm})$ fraction of soil and are developed in humid-temperate or warmer areas (Quirk 1996). Soil mineral phase in majority of soils is a complex mixture of phyllosilicate minerals which are most common minerals in soils and are composed of one or two sheets of $\mathrm{Si}$ (or isomorphically substituted $\mathrm{Al}$ ) in tetrahedral coordination with $\mathrm{O}$ fused to cations in octahedral coordination with $\mathrm{O}$ or $\mathrm{OH}$. Main characteristics of most secondary minerals are small particle size, high surface area and a net negative charge which enables them to participate in reactions with water molecules, nutrients, heavy metals, organic pollutants and toxic 
contaminants (Chesworth 2008). According to Kapelj et al. (2018) soils from Prošće Lake catchment have slightly acidic to neutral $\mathrm{pH}$ reaction and dominantly net negative charge.

Unlike organic matter, minerals have smaller absorption bands of greater intensity (Ramasamy et al. 2009). Peaks were determined for most important infrared-active groups occurring in mineral soils. The obtained results, with fewer exceptions, are well-matched with the absorption peak values of silicates and carbonates mentioned in the literature and the available FTIR spectrum databases. Small variations in values of $\mathrm{O}-\mathrm{H}$ bond stretching and bending vibrations is due to different strength of hydrogen bond between $\mathrm{O}-\mathrm{H}$ and $\mathrm{H}_{2} \mathrm{O}$ and oxygen in structures of minerals.

The Si-O bonds are the strongest bonds in the structure of silicate minerals and are easily detected on FTIR spectra. Silicate minerals have strong absorption bands ranging from 1100 to $900 \mathrm{~cm}^{-1}$ due to Si-O stretching and less intense bands ranging from 400 to $800 \mathrm{~cm}^{-1}$ due to $\mathrm{Si}-\mathrm{O}$ bending. The presence of quartz is cause of symmetrical bending in the range of $690-695 \mathrm{~cm}^{-1}$ and the

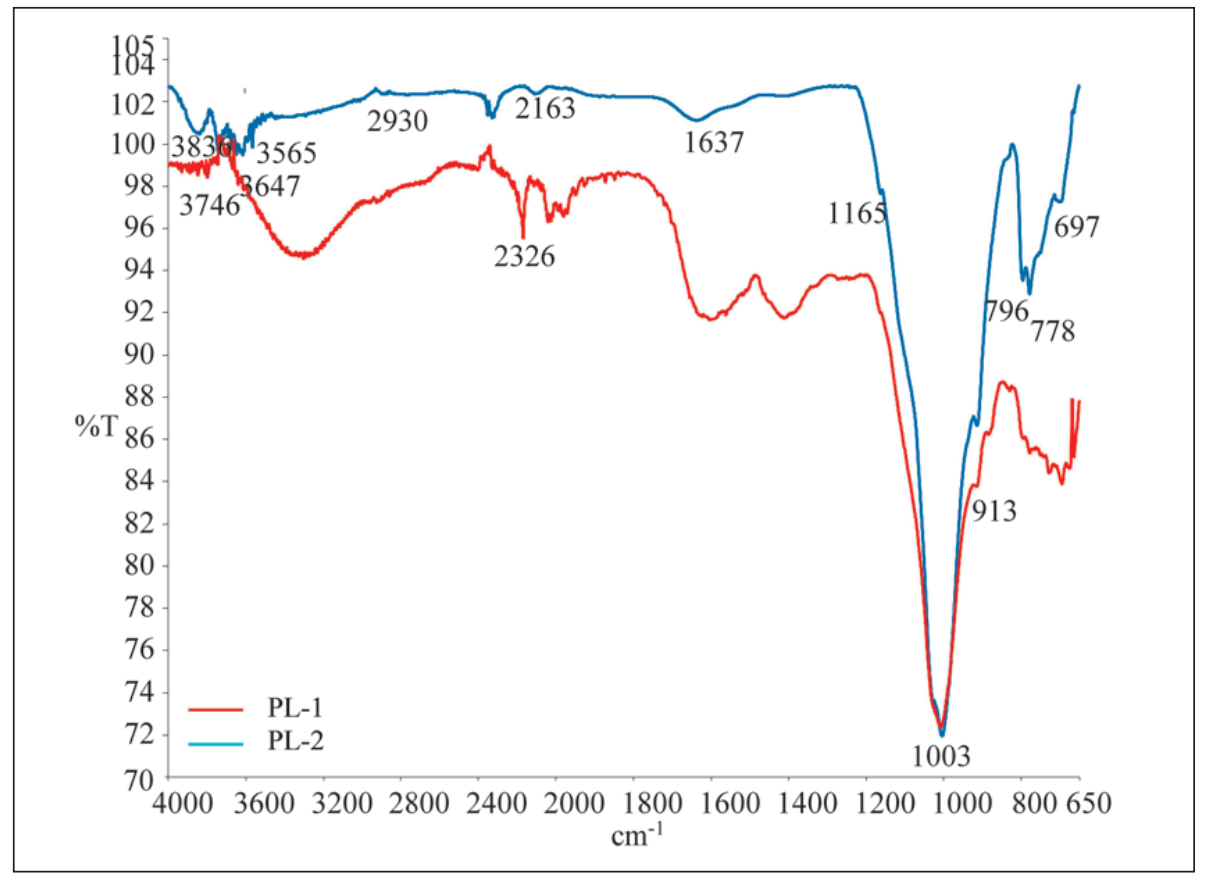

Fig. 4: FTIR spectra for soil samples $P L-1$ and $P L-2$.

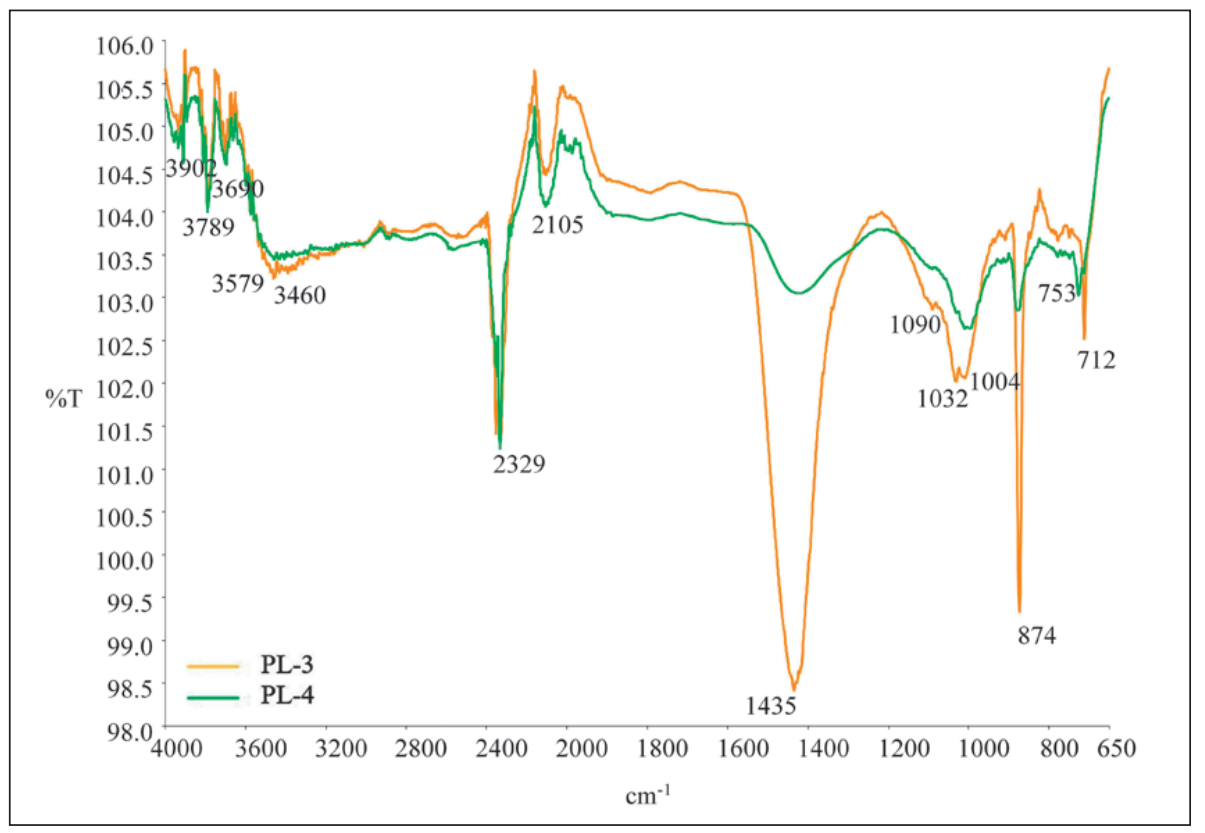

Fig. 5: FTIR spectra of stream sediment sample PL-3 and soil sample PL-4. 
vibration bands due to the symmetric stretching in the range of 776-780 and 795-800 $\mathrm{cm}^{-1}$. Bands characteristic for quartz are present in the spectra of all samples and are in good agreement with observations for the quartz mineral made by Ponnusamy et al. (2009) and Boldea et al. (2013).

FTIR spectra of clay minerals are complicated since the intensity and position of the absorption bands depends on the chemical composition and origin of clays, especially the presence of impurities (Khang et al. 2016). The doublet band visible in samples PL-3, PL-5, PL-7,
PL-9 and PL-10 (Figs. 5-7) in the range $1008-1032 \mathrm{~cm}^{-1}$ corresponds to the Si-O-Al and Si-O-Si stretching and the $1090 \mathrm{~cm}^{-1}$ band observed in samples PL-3, PL- 9 and PL-10 is due to normal-to-the-plane stretching of Si-O$\mathrm{Si}$ in aluminosilicate minerals, possibly illite. (Figs. 5-7) (Davarcioglu 2010: Essomba et al. 2014). Illite is a is a common mineral found in soils and sediments. Four bands at $3697 \mathrm{~cm}^{-1}, 3662 \mathrm{~cm}^{-1}, 3648 \mathrm{~cm}^{-1}, 3620 \mathrm{~cm}^{-1}$ present in samples are due to $\mathrm{OH}$ stretching in water molecules that may be an integral part of the mineral kaolinite (Fadil-Djenabou et al. 2015: Khang et al. 2016). Bands
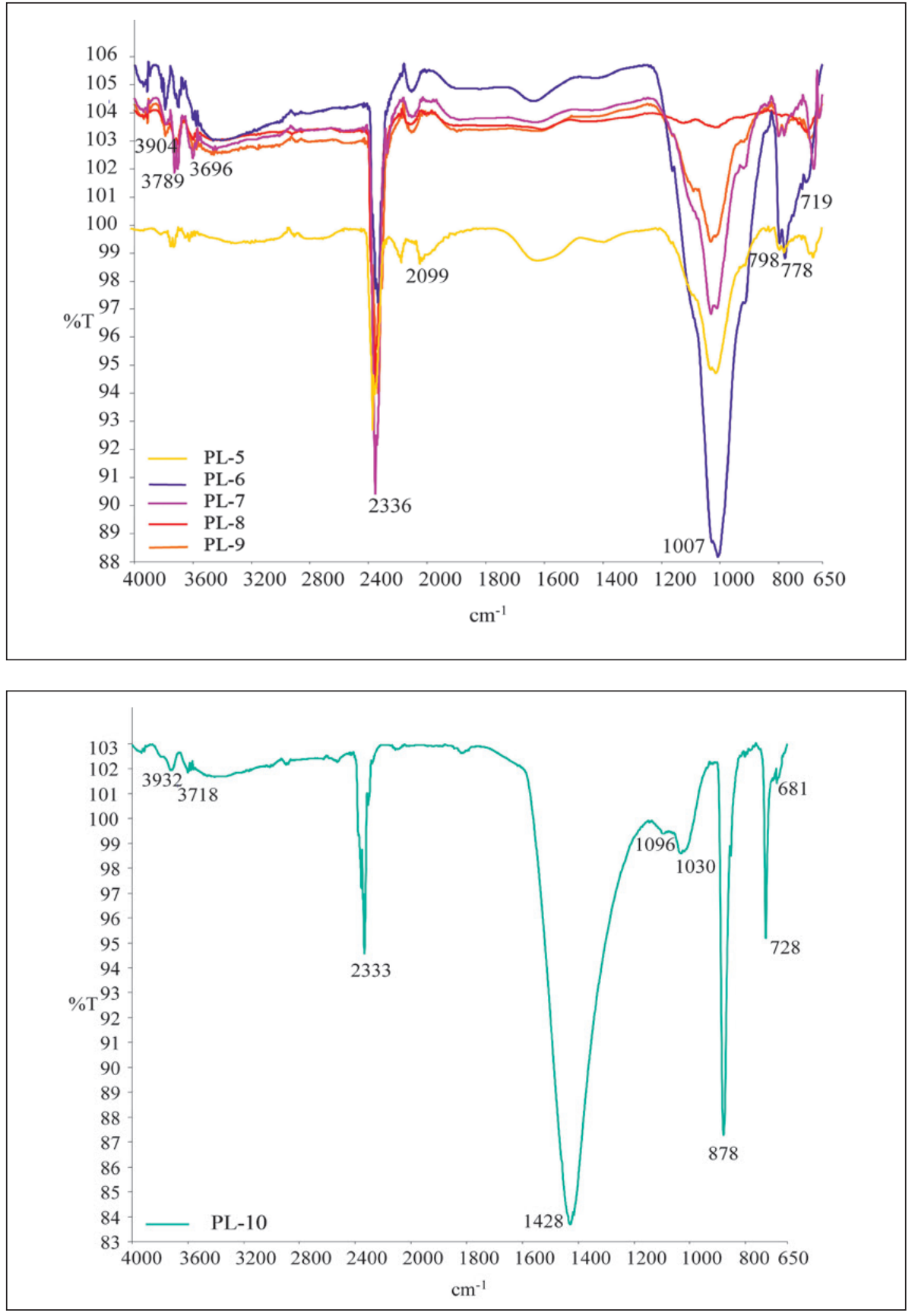

Fig. 6: FTIR spectra of soil samples PL-5, PL-6, PL-7, PL-8 and PL-9.
Fig. 7: FTIR spectra of soil sample PL-10. 
in the range 1698 to $1521 \mathrm{~cm}^{-1}$ can be ascribed to the bending mode of $\mathrm{H}_{2} \mathrm{O}$ molecules in the kaolinite. Kaolinite is a common soil mineral with a structural formula $\mathrm{Al}_{2} \mathrm{Si}_{2} \mathrm{O}_{5}(\mathrm{OH})_{4}$. It is a typical dioctahedral species with triclinic symmetry (Senthil Kumar \& Rajkumar 2014). Both organic matter and clay minerals, have an important role due to good ion exchange capacity in binding metal cations from water into a solid phase. Cation exchange capacity (CEC) values for soil samples from Prošće Lake catchment range from 16 to $175 \mathrm{cmol}(+) / \mathrm{kg}$ confirming the dominant influence of minerals like kaolinite and illite in majority of samples and organic matter in samples PL-1 (forest soil) and PL-5 (peat) (Kapelj et al. 2018).

Vibration bands centered at about $1600 \mathrm{~cm}^{-1}$ and $3400 \mathrm{~cm}^{-1}\left(3434,3565,3662 \mathrm{~cm}^{-1}\right)$ in samples PL-2, PL-4, PL-6, PL-7 and PL-9 are result of bending and stretching of $\mathrm{O}-\mathrm{H}$ bond which in our case is included in the transmittance spectrum of chlorite (Figs. 4-6) (Boldea et al. 2013: Fadil-Djenabou et al. 2015). Chlorite is a common weathering mineral whose structure consist of 2:1 layer with hydroxide sheet in the interlayer region. Since $\mathrm{Mg}$ and Fe are major octahedral cations in chlorite structure, due to chlorite environmental instability, it accounts for significant amount of $\mathrm{Mg}$ and other nutrients released to the soil solution (Proust et al. 1985).

Peaks characteristic for carbonate minerals are present in spectra of majority of samples. The absorption bands in the range $1420-1460 \mathrm{~cm}^{-1}$ in the room temperature FTIR spectra are the result of asymmetric stretching (Gunasekaran \& Anbalagan 2007). According to Socrates (2001) and Boldea et al. (2013) bands at 1432 and 874 $\mathrm{cm}^{-1}$ can be attributed to a functional $\mathrm{CO}_{3}{ }^{2-}$ group. Also, peaks characteristic for carbonates were observed at $726 \mathrm{~cm}^{-1}$ (vibrational bending), and at $881 \mathrm{~cm}^{-1}$ (out-ofplane bending). Strong absorption bands in the range $2300-2600 \mathrm{~cm}^{-1}$ can be attributed to calcite $\mathrm{CaCO}_{3}(\mathrm{Du}$ \& Zhou 2009). Band at $2628 \mathrm{~cm}^{-1}$ is due to C-O symmet- ric stretching mode vibration. Results obtained by FTIR analysis were confirmed by XRD analysis of samples.

The obtained results show that the studied samples contain minerals characteristic for soils developed on bedrock made of limestones and dolomites. Also, the composition of the soil is influenced by the rich plant cover characteristic for The Plitvice Lakes National Park, which is the source of organic matter in the soil.

\section{XRD}

Results of the X-ray powder diffraction analysis of the soil samples collected in Plitvice lakes catchment area are presented in the Tab. 2 and Figs. 8-9. As can be seen, 6 major mineral constituents are detected in studied samples. Quartz is present in all samples while only the sample PL-3 contains calcite. Dolomite, feldspar, chlorite and muscovite are present in majority of samples.

Sample PL-3 contains all detected minerals (Fig. 9). Unlike other samples, which are samples of soils, sample PL-3 is a stream sediment (Tab. 1). Halamić et al. (2001) defines stream sediment as "silty fraction (clay to finegrained sand) transported and deposited in a recent stream channel." It is a composite material whose petrographic, mineralogical and geochemical composition roughly reflects the bedrock lithology upstream from the sampling site in case the anthropologic influences are low or absent. Stream sediment is a result of erosion and transport of soil and rock debris, and other materials within catchment basin upstream of the sampling site (De Vos et al. 2019). In this case, stream sediment was taken at the exit point of Prošće lake and is a good representation of material being introduced into lakes system.

Since quartz is one of minerals most resistant to chemical weathering in soils and stable at ambient conditions (Glinneman et al. 1992), it is common and invariably present in all the samples. Dominant peaks for lowtemperature quartz are at $26.64^{\circ}$ and $20.86^{\circ} 2 \theta$ (Fig. 8).

Tab. 2: Mineralogical composition of investigated samples by XRD analysis: + (present), - (not detected).

\begin{tabular}{|c|c|c|c|c|c|c|}
\hline Sample & Quartz & Calcite & Dolomite & Feldspar & Chlorite & Muscovite \\
\hline PL-1 & + & - & + & + & + & + \\
\hline PL-2 & + & - & - & + & + & + \\
\hline PL-3 & + & + & + & - & - & + \\
\hline PL-4 & + & - & - & + & + & + \\
\hline PL-5 & + & - & + & + & + & + \\
\hline PL-6 & + & - & - & + & + & + \\
\hline PL-7 & + & - & - & + & + \\
\hline PL-8 & + & + & + & + & + & + \\
\hline PL-9 & + & + & + & + & + \\
\hline PL-10 & + & + & + & + \\
\hline
\end{tabular}


Samples contain considerable amounts of clay minerals and other layered silicates. Chlorite resembles $\mathrm{Mg}_{2.96} \mathrm{Fe}_{1.55}$ $\mathrm{Fe}_{0.136} \mathrm{Al}_{1.275} \mathrm{Si}_{2.662} \mathrm{Al}_{1.376} \mathrm{O}_{10}(\mathrm{OH})_{8}$, one of the most common members of the chlorite group. Clinochlore is a detrital component of sediments often associated with dolomite, calcite and plagioclase. Muscovite is present in majority of samples (Tab. 2).

Feldspar detected by XRD in samples is determined as the closest to anorthoclase $\mathrm{Na}_{0.667} \mathrm{~K}_{0.333} \mathrm{AlSiO}_{8}$. Anorthoclase is an alkali feldspar and is a common member of sodium-rich igneous rocks.

Carbonate minerals are very important component of the soil influencing chemical and physical properties like soil $\mathrm{pH}$ and buffer capacity. Carbonates in soil typically occur as calcite or dolomite depending on the parent material and soil formation processes (Bruckman \& Wriessnig 2013). Differentiation of soil carbonates into calcite and dolomite is valuable for determining sources of soil parent materials, degree of carbonate weathering, types of secondary carbonates, and the occurrence of dolomitization (Petersen et al. 1966). X-Ray diffraction allows a distinct differentiation between calcite $\mathrm{CaCO}_{3}$ and dolomite $(\mathrm{Ca}, \mathrm{Mg}) \mathrm{CO}_{3}$. Dominant peak for calcite is present at $29.4^{\circ} 2 \theta$ and for dolomite at $30.96^{\circ} 2 \theta$ (Fig. 9).
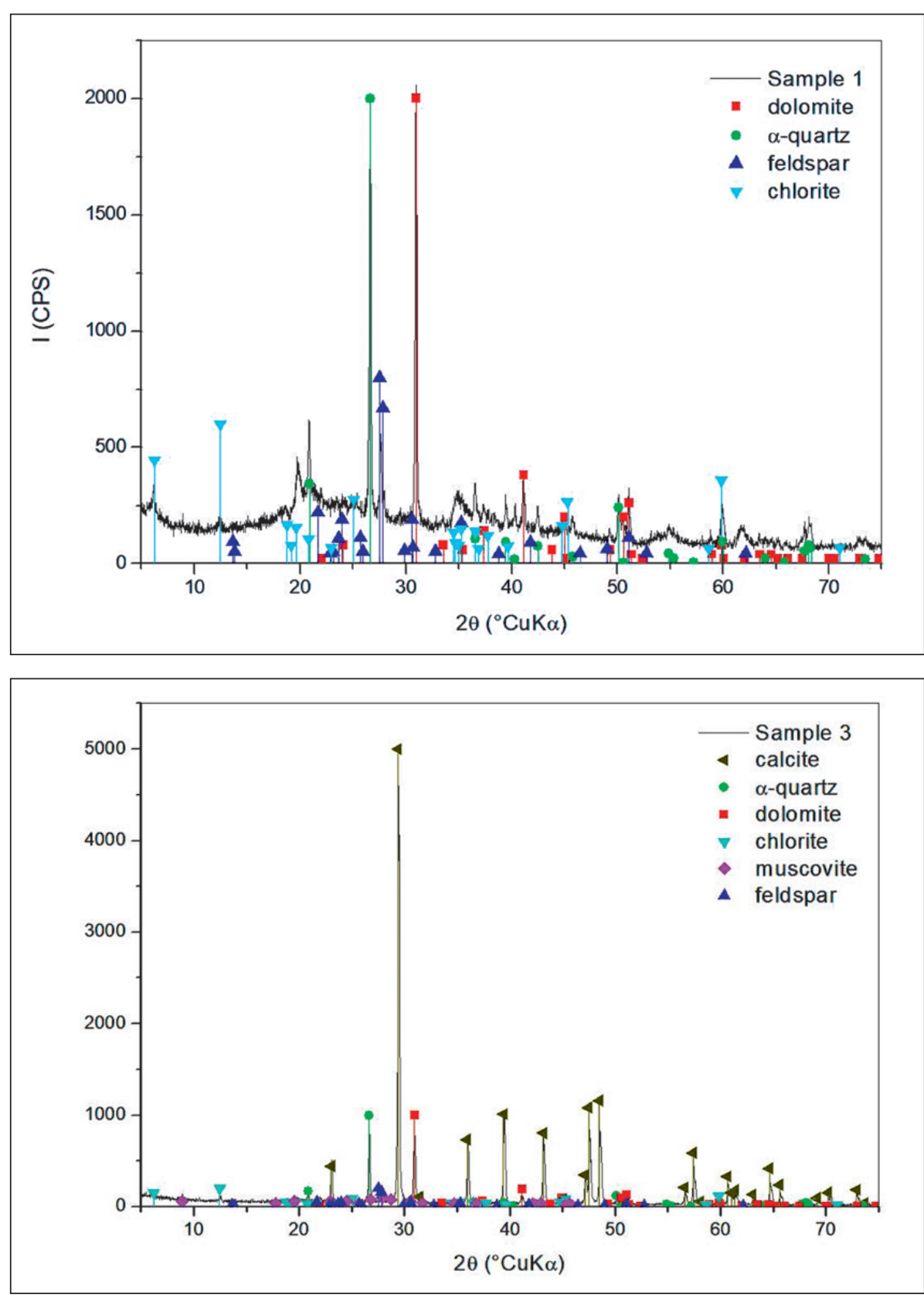

Fig. 8: Diffractogram of the sample PL-1.
Fig. 9: Diffractogram of the sample PL-3. 
X-ray diffractogram of sample PL-3 is the only one showing calcite in significant amounts (Fig. 9). This is expected since underlying rock is tufa, porous sedimentary rock built mainly from calcium carbonate. Calcite is prone to chemical weathering and has a better solubility in weak acids like precipitation and humic acids in soils in comparison to dolomite.

The results obtained by XRD soil analysis were compared with the results of Prošće Lake sediment analyzed by Popović et al. (1986). The study found that dominant mineral is quartz along with other rock forming minerals like feldspar, mica, chlorite and with traces of calcite and dolomite. Almost identical mineralogical composition of investigated soil samples and core samples taken from the Prošće Lake indicate there is a terrigenic input of soil material to the lake system.
Occasionally minerals species identified through FTIR can be absent in the XRD analysis. Reason could be in disorder and the loss of crystalline nature of the respective minerals or in the low detection limits of XRD for small quantities of minerals in mixed samples. Even the small amount of clay minerals (in form of coatings) can play a significant role in functioning of an ecosystem by affecting water storage properties, water quality, cation exchange capacity, etc. Good example for that is illite whose characteristic functional group vibrations were present in FTIR spectra but were not detected by XRD probably due to small amount of illite in samples. Also, the XRD peaks of some of the main soil minerals, like kaolinite, muscovite, sillimanite, may overlap with the strongest peak and other peaks of quartz (Singh \& Agrawal 2012).

\section{ENVIRONMENTAL SIGNIFICANCE OF DETECTED SOIL CONSTITUENTS}

Sedimentary material that originates outside the lakes is to be referred as allogenic. Different minerals can be brought into the lakes by surface waters, mainly streams and overland flow during snow thawing and rain, and during shore erosion.

Forests, on the one hand, protect lakes, and on the other, they are sources of organic matter, especially during the fall, increasing the possibility of eutrophication of the lakes (Biondić et al. 2017). All analyzed samples contain organic matter especially sample PL-5 which was taken from peat bog located at the confluence of Matica river to Prošće lake. Hence, when entering the lake, the waters of Matica are already enriched with organic matter. Organic matter plays an important role in process of lake formation since higher concentrations of it in water inhibit tufa production. Study made by Srdoč et al. (1985) showed that important factors in process of tufa formation are water $\mathrm{pH}$ above 8 , flow rate between $0.5-3.5 \mathrm{~m} / \mathrm{s}$, low concentrations of dissolved organic matter and activity of organisms, mainly mosses, algae and grasses. The analysis of cores taken from lake Prošće and Kozjak have shown high content of organic matter and related high concentrations of phosphorus. Organic matter can also serve as the means of transportation for heavy metals and other pollutants. Horvatinčić et al. (2006) noticed positive correlation between concentrations of organic carbon and concentrations of $\mathrm{Pb}, \mathrm{Cd}$ and $\mathrm{Zn}$. Also, concentrations of organic matter decrease downstream.

Dispersed clay-size particles of soils and sediments contribute to the suspended load in surface waters and serve as the means of nutrients and contamination trans- port via adsorption to particle surface. Based on soil mineralogy, predictions can be made about soil's tendency to disperse. Soils rich in smectites are highly dispersive and more likely to end up in surface waters than soils rich in kaolinite or illite (Calero et al. 2008). Smectite was not detected in the tested soils, which significantly reduces the possibility of dispersion of the observed soils.

The most abundant mineral in the samples is quartz because of its thermodynamic resistance to weathering. Quartz can be of eolian origin or it can be a residue after dissolution of limestones containing small amount of quartz. Quartz has a very low CEC value since it has almost insignificant amount of charge. When compared to other soil minerals, quartz has almost diluting effect on the overall value of CEC (Dixon \& Schulze 2002). Since quartz is the most common mineral in the mineral phase of soil, it is expected that it is also present in lake sediments. Concentrations of quartz in core samples taken from Prošće lake fluctuate around $10 \%$ along $40 \mathrm{~cm}$ long sediment core representing 100 - 200 years of sedimentation. (Horvatinčić et al. 2006). Minor variations in concentration reflect the fairly constant input of terrigenous material in the Prošće lake over the years.

Muscovite is a widely distributed soil component whose dissolution is a possible source of $\mathrm{K}$ and $\mathrm{Mg}$ in the soil solution. Estimating the capacity of micaceous minerals to supply $\mathrm{K}$ to the soil solution is a key for estimate of plant nutrition and development. Healthy and well-developed vegetation has a substantial influence on precipitation, transport and deposition of ions and nutrients. Water infiltration is much slower on terrains cov- 
ered with thick vegetation and also, erosion processes are much slower. On the other hand, soil and vegetation enhance chemical weathering through hydrological impact and by providing organic acids (Kamenik 2001). Size of the particles also has a noteworthy role since smaller particles loose K faster than the bigger one (Dixon \& Schulze 2002). Also, alteration of micas, including muscovite, in diagenetic environments results in formation of expandable 2:1 phyllosilicates of the vermiculite and smectite groups (Kalinowski \& Schweda 1996). Muscovite has a considerably lower cation exchange capacity (CEC) than smectites because only its surface cations can be exchanged at room temperature (Osman \& Suter 2000).

Chlorite detected in soil samples has a substantial amount of iron in formula. Structural $\mathrm{Fe}^{2+}$ plays a significant role in weathering of $\mathrm{Fe}$-containing species. Weathering of chlorites occurs through progressive hydration of the interlayer hydroxide sheet with consequent loss of cations and results in formation of vermiculite or smectite both having very high CEC values. Nitrate contamination of groundwater has become a grave risk in some areas of world. Nitrogen is an essential nutrient in aquatic ecosystems but rise in nutrient availability can result in eutrophication. Chemical changes are followed by changes in biological productivity, the composition and variety of biota and, accordingly, in physical status of water bodies (Hornung 1999). Ferrous ion in chlorites can reduce $\mathrm{NO}_{3}^{-}$to $\mathrm{NH}_{4}^{+}$(Ernsten 1996) and may contribute to the removal of organic contaminants and $\mathrm{NO}_{3}^{-}$from the soil solution and groundwater under reducing conditions.
Calcite and dolomite in soil samples can originate from underlying limestones, dolomites and tufas and cannot be considered pedogenic, unlike the calcite and dolomite that can be formed by dissolution and reprecipitation of calcium and magnesium containing minerals or it can be part of wind and tropospheric deposition. The amount of the dissolved organic matter (DOC) in soils are very important since even the low levels of DOC can inhibit calcite nucleation and precipitation. Calcite is a significant scavenger of several trace elements and plant nutrients $(\mathrm{P}, \mathrm{Sr}, \mathrm{Pb})$ in natural setting. It provides a surface for direct sorption of metal ions and it influences soil $\mathrm{pH}$. Chemisorption of elements on calcite depends primarily of their ionic radius and can be a very fast process, in some cases almost irreversible (for example, chemisorption of Cd). Surface protonation - deprotonation reactions on calcite create negative surface charge at $\mathrm{pH}$ values 8,5 to 9 and positive charge below that $\mathrm{pH}$ range (Dixon \& Schulze, 2002). Soil of the area of interest are slightly acidic to neutral so it is expected that calcite has a positive surface charge and can bind negatively charged ions and particles. Calcite has been found to be the dominant mineral phase in recent lake sediments with concentrations up to $70 \%$ (Horvatinčić et al. 2006; Horvatinčić et al. 2014). It is expected that most calcite in lake sediments is autigenic, but it cannot be neglected that one small part is of terrigenous origin and primarily occurs in the sediments of Prošće Lake in the vicinity of the Matica river.

\section{CONCLUSION}

The Plitvice Lakes are very vulnerable aquatic ecosystem which is exposed to significant inputs of materials from their recharge areas. Its unique beauty attracts around 1 million visitors a year making this fragile ecosystem very susceptible to anthropogenic influence. In order to maintain the continuity of the tufa production, it is essential to maintain exceptional water quality. Since terrigenic input can also be a source of different pollutants in water and lake sediment, it is important to understand physicalchemical characteristics of the soil in recharge area, specifically mineralogical composition of soils.

FTIR and XRD analysis of soil, peat and stream sediment samples gave us insight into soil mineralogy and characteristics that come from it. FTIR and XRD results shown that dominant minerals in studied samples are quartz, muscovite, feldspar, chlorite, calcite and do- lomite and soils contain significant amounts of organic matter. Considering the analyzed samples and characteristics of detected soil constituents, soils and sediments in the Prošće Lake catchment have the ability to retain and purify water on its way to the lakes. On the other hand, terrigenic input, although small, cannot be neglected. In case of the possible contamination in the recharge area of the lakes system, the pollutants can enter the system adsorbed on the soil particles. Due to the preservation and good condition of the forests and soils in the catchment of lake Prošće, terrigenous intake still does not pose a threat to water quality and tufa production. Learning more about the soils surrounding lakes gives valuable insight into their possible influence on lakes water chemistry and adds one piece of the puzzle into understanding this kind of a natural phenomenon. 


\section{ACKNOWLEDGMENTS}

The work has been supported by Plitvice Lakes National Park Public Institution through research project entitled "Hydrodynamic modeling of the Plitvice Lakes system" and with assistance of employees of Dr. Ivo Pevalek Scientific Research Center.

\section{REFERENCES}

Babinka, S., 2007: Multi-tracer study of karst waters and lake sediments in Croatia and Bosnia and Herzegovina: Plitvice Lakes, National Park and Bihać area.Ph.D. thesis, Rheinischen Friedruch-WilhelmsUniversitat, Bonn, Germany, pp. 167.

Biondić, B., Zojer, H., Biondić, R., Beyene, Y., Kapelj, S., Meaški, H. \& G. Zwicker, 2008: Mountainous lakes - Sustainable utilization of water in the pilot area Plitvice Lakes.- In: Probst, G. et al. (eds.): Wasserressourcen und deren Bewirt-schaftung - Die Bedeutung von Netzwerken. Internationale Fachtagung. Kompetenznetzwerk Wasserressourcen $\mathrm{GmbH}$, pp. 109-117, Graz.

Biondić, B., Biondić, R. \& H. Meaški, 2010: The conceptual hydrogeological model of the Plitvice Lakes. Geologia Croatica, 63, 2, 195-206. https://doi. org/10.4154/gc.2010.17

Biondić, B., Biondić, R. \& H. Meaški, 2017: Water resources protection in the NP Plitvice Lakes.- In: Proceedings of Scientific and technical conference with international participation Managing lakes and reservoirs in Croatia - process, protection and evaluation and round table on current problems of Vransko lake near Biograd na Moru, May 4-6, 2017.

Bish, D.L. \& R.C. Reynolds, Jr. 1989: Sample preparation for X-ray diffraction.- In: Bish D.L. \& J.E. Post (eds.): Modern Powder Diffraction, Reviews in Mineralogy 20, Mineralogical Society of America, pp. 73-99, Washington, D.C.

Boldea, D. A., Praisler, M., Quaranta, M., \& V. Minguzzi, 2013: Multi-technique characterisation of painted eneolithic ceramics originating from Cucuteni (Romania).- European Journal of Science and Theology, 9, 4, 253-262. http://dx.doi.org/10.1016/j.jeurceramsoc.2017.07.018.

Bruckman, V. J. \& K. Wriessnig, 2013: Improved soil carbonate determination by FT-IR and X-ray analysis.- Environmental Chemistry Letters, 11, 1, 65-70. https://doi.org/10.1007/s10311-012-0380-4

Calero, N., Barrón, V. \& J. Torrent, 2008: Water dispersible clay in calcareous soils of southwestern Spain.-
CATENA, 74, 1, 22-30. https://doi.org/10.1016/j. catena.2007.12.007

Chesworth, W., 2008. Encyclopedia of Soil Science.Springer, pp. 902, Netherlands.

Dautović, J., Fiket, Ž., Barešić, J., Ahel, M. \& N. Mikac, 2014: Sources, Distribution and Behavior of Major and Trace Elements in a Complex Karst Lake System.- Aquatic Geochemistry, 20, 19-38. https:/doi. org/10.1007/s10498-013-9204-9

Davarcioglu, B., 2010: Investigation of Central Anatolian region Nigde-Dikilitas (Turkey) clays by FTIR spectroscopy.- Journal of Silicate Based and Composite Materials, 62, 2, 55-60. http://dx.doi.org//10.14382/ epitoanyag-jsbcm.2010.12

Davarcioglu, B., 2012: Kolsuz-Ulukisla-Nigde Clays, Central Anatolian Region - Turkey and Petroleum Exploration.- Clay Minerals in Nature - Their Characterization, Modification and Application, 1, 3954. https://doi.org/10.5772/48286

De Vos, W., Batista, M.J., Pirc, S., O'Connor, P.J., Demetriades, A., Tarvainen, T., Salminen, R., Reeder, S., Salpeteur, I. \& V. Gregorauskiene, 2019: Distribution of elements in stream sediment.- [Online] Available from: http://weppi.gtk.fi/publ/foregsatlas/ article2.php?id=28 [Accessed 26th January 2019]

Dixon. J. B. \& D. Schulze (eds.), 2002: Soil Mineralogy with Environmental Applications.- SSSA Book series 7, Soil Science Society of America, pp. 866, Madison, Wisconsin, USA.

Du, C. \& J. Zhou, 2009: Evaluation of soil fertility using infrared spectroscopy: A review.- Environmental Chemistry Letters, 7, 2, 97-113. https://doi. org/10.1007/s10311-008-0166-x

Ernsten, V., 1996: Reduction of nitrate by $\mathrm{Fe}^{2+}$ in clay minerals.- Clays and Clay Minerals, 44, 5, 599-608.

Essomba, J. S., Nsami, N. J., Belibi Belibi, P.D., Merlain Tagne, G. \& J. Ketcha Mbadcam, 2014: Adsorption of cadmium (II) ions from aqueous solution onto kaolinite and metakaolinite.- Pure and Applied Chemical Sciences, 2, 11-30. http://doi. org/10.12988/pacs.2014.31017

Fadil-Djenabou, S., Ndjigui, P. D. \& J. A. Mbey, 2015: 
Mineralogical and physicochemical characterization of Ngaye alluvial clays (Northern Cameroon) and assessment of its suitability in ceramic production.- Journal of Asian Ceramic Societies, 3, 1, 5058. http://doi.org/10.1016/j.jascer.2014.10.008

Filipčić, A., 1998: Climatic regionalization of Croatia according to W. Köppen for the standard period 19611990 in relation to the period 1931-1960 [in Croatian].- Acta Geographica Croatica, 33, 1-15.

Glinnemann, J. I., King, H. E., Schulz, H., Hahn, T., La Placa, S. J. \& F. Dacol, 1992: Crystal structures of the low-temperature quartz-type phases of $\mathrm{SiO} 2$ and $\mathrm{GeO} 2$ at elevated pressure.- Zeitschrift für Kristallographie, 198, 177-212. https://doi.org/10.1524/ zkri.1992.198.14.177

Gunasekaran, S. \& G. Anbalagan, 2007: Thermal decomposition of natural dolomit.- Bulletin of Materials Science, 30, 4, 339-344. http://doi.org/10.1134/ S0020168511120156

Halamić, J. \& S. Miko (eds.), 2009: Geochemical Atlas of the Republic of Croatia.- Croatian Geological Survey, pp. 87, Zagreb.

Halamić, J., Peh, Z., Bukovec, D., Miko, S. \& L. Galović, 2001: A Factor Model of the Relationship between Stream Sediment Geochemistry and Adjacent Drainage Basin Lithology, Medvednica Mt., Croatia.- Geologia Croatica, 54, 1, 37-51.

Hornung, M., 1999: The Role of Nitrates in the Eutrophication and Acidification of Surface Waters.- In: Wilson W.S. et al. (eds.) Managing Risks of Nitrates to Humans and the Environment. Woodhead Publishing, pp. 155-174, Sawston, Cambridge. http:// doi.org/10.1533/9781845693206.155

Horvatinčić, N., Briansó, J. L., Obelić, B., Barešić, J. \& I. Krajcar Bronić, 2006: Study of pollution of the Plitvice Lakes by water and sediment analyses.- Water, Air, \& Soil Pollution: Focus, 6, 475-485. http://doi. org/10.1007/s11267-006-9031-8

Horvatinčić, N., Sondi, I., Barešić, J., Sironić, A., Krajcar Bronić, I., Obelić, B., Vdović, N. \& A. Rajtarić, 2014: Utjecaj klimatskih promjena i stanja u okolišu na biološki inducirano taloženje sedre i sedimentacijske procese u Plitvičkim jezerima.- Završno izvješće IRB-ZEF-2014/2.

Kalinowski, B. E. \& P. Schweda, 1996: Kinetics of muscovite, phlogopite, and biotite dissolution and alteration at $\mathrm{pH} 1-4$, room temperature.- Geochimica et Cosmochimica Acta, 60, 3, 367-385. https://doi. org/10.1016/0016-7037(95)00411-4

Kapelj, S., Dogančić, D., Plantak, I. \& J. Loborec, 2018: Origin and distribution of cadmium in soils of NP Plitvice Lakes. In: Rubinić J. et al. (eds.): Proceedings of Hydrology in service of water protection, water use and flood risk reduction - recent trends and approaches, 18-20 ${ }^{\text {th }}$ October 2018 Brela, Croatia. Croatian Hydrological Society, 45-52, Zagreb.

Khang, V. C., Korovkin, M. V. \& L. G. Ananyeva, 2016: Identification of clay minerals in reservoir rocks by FTIR spectroscopy.- In: OP Conference Series: Earth and Environmental Science, Volume 43, XX International Scientific Symposium of Students, Postgraduates and Young Scientists on "Problems of Geology and Subsurface Development" 4-8 April 2016, Tomsk, Russia 43, 1. http://doi.org/10.1088/17551315/43/1/012004

Kottek, M., Grieser, J., Beck, C., Rudolf, B. \& F. Rubel, 2006: World Map of the Köppen-Geiger Climate Classification Updated.- Meteorologische Zeitschrift. 15, 259-263. http://doi.org/10.1127/09412948/2006/0130

Kritzberg, E. S., Langenheder S. \& E. S. Lindström, 2006. Influence of dissolved organic matter source on lake bacterioplankton structure and function - implications for seasonal dynamics of community composition.- FEMS Microbiology Ecology, 56, 3, 406-417. https://doi.org/10.1111/j.15746941.2006.00084.x

Margenot, A. J., Calderón, F. J., Goyne, K. W., Mukome, F. N. \& S. J. Parikh, 2017: IR Spectroscopy, Soil Analysis Applications.- In: Lindon J.C. et al. (eds.) Encyclopedia of Spectroscopy and Spectrometry. Academic Press, pp. 448-454, Cambridge, Massachusetts. https://doi.org/10.1016/B978-0-12-4095472.12170-5

Matin, J., 2017: Procjena ranjivosti krških vodonosnika na primjeru sliva Plitvičkih jezera.- Master thesis. University of Zagreb, Faculty of Geotechnical Engineering, pp. 53.

Meaški, H., 2011: Model of the karst water resources protection on the example of the Plitvice Lakes National Park.- PhD thesis. University of Zagreb, Faculty of Mining, Geology and Petroleum Engineering, pp. 210.

Meaški. H., Biondić, B. \& R. Biondić, 2016: Delineation of the Plitvice Lakes karst catchment area, Croatia.In: Stevanović, Z. et al. (eds.), Karst without Boundaries. CRC Press/Balkema, pp. 269-284, Holland.

Mikac, I., Fiket, Ž., Terzić, S., Barešić, J., Mikac, N. \& M. Ahel, 2011: Chemical indicators of anthropogenic impacts in sediments of the pristine karst lakes.- Chemosphere, 84, 8, 1140-1149. https://doi. org/10.1006/jcis.1999.6677

Osman, M. A. \& U. W. Suter, 2000: Determination of the Cation-Exchange Capacity of Muscovite Mica.Journal of Colloid and Interface Science, 224, 1, 112-115. https://doi.org/10.1006/jcis.1999.6677 
Petersen, G. W., Chesters, G. \& G. B. Lee, 1966: Quantitative determination of calcite and dolomite in soils.-Journal of Soil Science, 17, 328-338. http:// doi.org/10.1111/j.1365-2389.1966.tb01477.x

Ponnusamy, V., Ramasamy, V. \& P. Rajkumar, 2009: Depth wise analysis of recently excavated Vellar river sediments through FTIR and XRD studies.Indian Journal of Physics, 83, 9, 1295-1308. http:// doi.org/10.1007/s12648-009-0110-3

Popović, S., Srdoč, D. \& S. Grgić, 1986: Investigation of Lake Sediments and Tufa in the National Park Plitvice by X-ray Diffraction and Optical Microscopy.Zbornik 5. skupa sedimentologa Jugoslavije, Brioni 2.-5.06. 1986. Hrvatsko geološko društvo, pp. 140142 , Zagreb.

Proust, D., Eymer, J.P. \& D. Beaufort, 1986: Supergene vermiculization of magnesian chlorite: Iron and magnesium removal processes.- Clays and Clay Minerals, 34, 572580.

Quirk, J.P., 1996: Interparticle forces: a basis for the interpretation of soil physical behavior.- Advances in Agronomy, 53, 121-183.

Romanić Herceg, S., Kljaković - Gašpić, Z., Bituh, T., Žužul, S., Dvoršćak, M., Fingler, S., Jurasović, J., Klinčić, D., Marović, G., Orct, T., Rinkovec J. \& S. Stipičević, 2016: The impact of multiple anthropo- genic contaminants on the terrestrial environment of the Plitvice Lakes National Park, Croatia.- Environmental Monitoring and Assessment, 188, 1, 1-16. https://doi.org/10.1007/s10661-015-5030-4

Socrates, G., 2001: Infrared and Raman characteristic group frequencies.- John Wiley and Sons Ltd, pp. 366, Chichester. https://doi.org/10.1002/jrs. 1238

Srdoč, D., Obelić, B., Horvatinčić, N., Krajcar Bronić, I., Marčenko, E., Merkt, S., Wong, H. \& A. Sliepčević, 1986: Radiocarbon dating of lake sediments from two karstic lakes in Yugoslavia.- Radiocarbon, 28, 2A, 495-502. https://doi.org/10.1017/ S0033822200007633

Sremac, J., Božičević S. \& I. Marković, 2012: Plitvice Lakes National Park (Central Croatia) - more than 50 years of continuos monitoring of natural and human influence.- European Geologyst, 34, 12-16.

Vrbek, B., 2005: Quality of precipitation and soil solution in the national parks "Plitvice lakes", "Northern Velebit" and "Risnjak".- Radovi, 40, 1, 19-30.

Zaharescu, D. G., Hooda, P. S., Soler, A. P., Fernandez, J. \& C. I. Burghelea, 2009: Trace metals and their source in the catchment of the high altitude Lake Respomuso, Central Pyrenees.- Science of the Total Environment, 407, 11, 3546-3553. https://doi. org/10.1016/j.scitotenv.2009.02.026 